\title{
Product Market Power, Industry Structure, and Corporate Earnings Management
}

\author{
Sudip Datta* \\ Department of Finance \\ School of Business Administration \\ Wayne State University \\ 5201 Cass Avenue \\ Detroit, MI 48202 \\ Tel: (313) 577-0408, Fax: (313) 577-0058 \\ Mai Iskandar-Datta \\ Department of Finance \\ School of Business Administration \\ Wayne State University \\ 5201 Cass Avenue \\ Detroit, MI 48202 \\ Tel: (313) 577-0408, Fax: (313) 577-9509 \\ Vivek Singh \\ Department of Finance and Accounting \\ College of Business \\ University of Michigan-Dearborn \\ Dearborn, MI \\ Tel: 313-271-9837, Fax: (313) 583-6533
}

*Corresponding Author: Sudip Datta, Department of Finance - Prentis 216, School of Business Administration, Wayne State University, 5201 Cass Avenue, Detroit, MI 48202, Tel: (313) 577-0408, Fax: (313) 577-0058, e-mail: sdatta@wayne.edu 


\title{
Product Market Power, Industry Structure, and Corporate Earnings Management
}

\begin{abstract}
This is the first study to establish a link between product market power of firms and the degree of earnings management. We hypothesize and document a significant and robust association between (a) a firm's product market pricing power and its degree of earnings management, and (b) industry competitiveness and the degree of earnings management in the industry. Our study reveals that firms with inferior product market pricing power engage in greater discretionary earnings accruals, adding a new dimension to our understanding of the transparency and quality of firms' financial statements. These findings are mirrored at the industry level where we document that more competitive industries are associated with greater earnings manipulation. The empirical evidence has direct implication on the informativeness and earnings quality of firms based on their product market power and competitiveness.
\end{abstract}

JEL classification: G30; L11; M4; M41

Keywords: Product market power; industry structure and competition; earnings management; discretionary accruals management. 


\section{Product Market Power, Industry Structure, and Corporate Earnings Management}

\section{Introduction}

A number of studies establish that a firm's product market environment influences its investments, financing, cash distributions, corporate governance and hedging decisions (see e.g., Haushalter, Klasa and Maxwell (2006), Grullon and Michaely (2007) and Fama (1980)). ${ }^{1}$ Yet how product market power impacts the strategic decision to manage a firm's reported earnings is an issue that has largely been overlooked. A central issue in earnings management research is to identify which firms have a propensity to engage in earnings manipulation. Much of the literature on earnings management delves into the degree to which firms are able to "game" the capital markets through earnings manipulation. However, we know very little about firm attributes that drive earnings management. In fact, Healy and Whalen (1999) state "These studies point to the value of further research to explain how business factors drive accruals."

In this study we argue that a firm's pricing power has the potential to influence the degree of earnings management for a number of reasons. First, pricing power can serve as a cushioning mechanism that affords the firm the ability to pass on any cost shocks to the customers, reducing cash flow fluctuations, and thereby diminishing the need to manipulate earnings. Second, in light of the fact that the market punishes firms when they fail to meet earnings expectations, one can argue that firms under weak pricing power are more likely to manipulate earnings to meet market expectation. Another motivation for earnings manipulation is to strategically limit and obfuscate the information available to rivals in an attempt to maintain a competitive advantage. Thus firms facing greater competitive pressures may be motivated to manage earnings to limit information available to

\footnotetext{
1 There is also a substantial body of theoretical research examining the link between product market power and its disciplinary effect on managerial behavior (see, for example, Holmstrom, 1982; Hermalin, 1992; Aghion, Dewatripont and Rey, 1999; and Raith, 2003).
} 
their rivals. Thus, the potentially important link between product market pricing power of firms and earnings management remains unexplored. The primary focus of this study is to address whether product market power influences the degree of earnings manipulation by corporate managers.

Specifically, we seek to answer the following questions: Is there a link between product market pricing power and the transparency of firm's reported earnings? Put differently, does pricing power that affords firms the ability to pass on cost shocks to customers lead to less earnings manipulation? Or, does lack of pricing pressure on firms that enjoy high product market power exacerbates earnings management? How does corporate governance influence the managerial decision to manage earnings in light of its product market pricing power? How does industry competitiveness influence corporate earnings management?

This study contributes to the finance and accounting literatures by documenting how a firm's relative product market pricing power and industry competitiveness determine earnings management decisions. Based on a comprehensive sample of 43,628 firm-year observations during the period spanning 1987-2009, our study documents that product market power is an important determinant of corporate earnings transparency. Notably, our analysis shows that firms with inferior product market pricing power engage more in discretionary accruals management, which suggests that such firms strategically act to limit transparency in their financial reporting. This validates the notion that the ability of high market power firms to pass on cost shocks to customers reduces the need to use accruals manipulation. Our evidence does not support the view that product market pricing pressure is effective in enhancing the transparency of financial reporting.

We extend our analysis by also examining different measures of industry competition and their relationship to earnings management. Using three alternative proxies of industry competition, our results indicate that the greater the competition in an industry, the greater the earnings management indicating that a lack of competitive environment diminishes the need to engage in earnings 
manipulation. Moreover, all our findings are highly robust to controlling for (a) internal and external disciplinary governance mechanisms, (b) executive compensation, and (c) the firm's information environment, indicating that governance factors cannot be considered substitutes for product market pricing power or competitiveness in an industry. We delineate the differences between product market pricing power and industry competition in the following section.

Our results are somewhat in contrast to Dalia and Park (2009) finding. Their conclusions are based on Herfindhal-Hirschman Index from the Census of Manufacturers. Thus their sample is restricted to manufacturing firms that is approximately one-third of our sample and uses census survey data that is updated only intermittently. However our results are consistent with the findings of Markarian and Santalo (2010) who apply different measures of product market competition and compute discretionary accrual differently than in our study but draw the sample from COMPUSTAT similar to us.

To the extent that earnings management can distort the financial picture of the firm, our analysis should help investors better understand the association between a firm's product market power and the degree of earnings manipulation, thereby enhancing their ability to gauge the real numbers behind the reported earnings ${ }^{2}$. By addressing the relevance of product market power to propensity of management to manipulate earnings, this study contributes to the earnings management research in accounting and finance, as well as the industrial organization (product market power) literature. The remainder of the paper is structured as follows. Section 2 presents the background literature and formulates the hypotheses. Sample formation, measurement of product

\footnotetext{
${ }^{2}$ Although our results are consistent with firms' product market competitive position leading to earnings management, we cannot rule out completely the possibility that this relationship could be endogenous as Bagnoli and Watts (2010) argue.
} 
market power, industry-level competition measures, and description of the sample are presented in Section 3. Section 4 presents the empirical findings. Section 5 concludes.

\section{Background literature and hypotheses development}

\subsection{Background literature}

Financial reporting is a key source of information to capital markets. Opportunistic earnings manipulation subverts the purpose of financial reporting by distorting firm's true economic performance, and thus can act as a hindrance to the full flow of information to market participants leading to higher informational asymmetry. The degree to which firms manipulate earnings has ramifications for the informativeness and reliability of reported financial statements for firms.

A survey of CFOs by Graham, Harvey and Rajgopal (2005) documents that earnings management is pervasive. They report that a vast majority of managers admit to smoothing earnings via manipulation of real or accrual activities on to influence the stock price and firm's risk premium. Skinner and Sloan (2002) show that managers manipulate earnings to avoid revealing the true value of their firms because reporting lower than expected earnings is severely penalized by financial markets.

Researchers have addressed various aspects of discretionary earnings management. A prominent focus of this body of work is on capital markets based incentives to manipulate earnings, such as boosting stock prices (Collins and Hribar, 2000), and obtaining lower financing costs (Dechow et al., 1996). Past studies have also documented that managing reported earnings is intended to influence the decisions of external capital providers. In particular, some research reports that managers inflate earnings prior to seasoned equity offerings, initial public offerings, and stockfinanced acquisitions (Teoh, Welch and Wong, 1998; Rangan, 1998; Erickson and Wang, 1999) while other studies provide evidence that earnings are managed downward prior to management buyouts (Perry and Williams, 1994). In contrast to this strand of research that focuses on managerial 
discretion in reported earnings around a certain event, the focal point in this study is distinctly different because it addresses whether the firm's product market power is a major driving force behind earnings management.

\subsection{Hypotheses development}

Intra-industry pricing power (which we interchangeably refer to as product market power) emanates from the firm's ability to extract abnormal rents (higher prices) from its customers without impacting demand, thus conferring a competitive pricing edge to the firm. Uniqueness and superiority of product lines or a strong brand name are the hallmarks of strong pricing power and competitive advantage. While industry-wide elasticity of demand is determined by the aggregate demand curve for the industry, intra-industry product differentiation (among firms within the industry) can affect the price elasticity of demand faced by a specific firm, regardless of the industry structure in which it operates. Research in this area has identified multiple advantages from such pricing power.

First, firms with greater pricing power can better maintain their profit margins when they are subject to exogenous productivity shocks because of the uniqueness of their products and/or strong brand name. Greater product differentiation (or lower product substitutability) can lead to more inelastic (rigid) demand curve for a firm's products, which affords the firm the flexibility to pass on cost shocks to its customers. ${ }^{5}$

To see how cost shocks impact firms within a specific industry, consider two firms: Firm A has differentiated its products from the rest of the industry and is able to command higher prices and Firm B has undifferentiated products (i.e. experiences greater product substitutability) and hence a decreased ability to raise prices. Firm A exhibits greater product market power than Firm B by virtue of its ability to extract a greater price from its customers in the face of an idiosyncratic cost

\footnotetext{
${ }^{5}$ Price competition increases with increased product substitutability (see Salop, 1979).
} 
shock. In other words, it enjoys less price competition. Thus, the inability of firms with weak pricing power to pass on cost shocks and protect profit margins serves to exert more pressure on them to manage earnings. In contrast, greater product market power enables firms to reduce the uncertainty about their future cash flows without resorting to earnings management.

Not only does pricing power confer on the firm a greater ability to absorb production cost shocks, but the pricing strength of such firms endows them with superior staying power by permitting them more flexibility in responding to unexpected changes in consumer product needs. Pricing power gives these firms deeper pockets, allowing them to maintain their superior positions while providing a cash flow cushion. We argue that the enhanced immunity level of these firms against cash shortfalls, increases their capability to face deteriorating economic conditions vis-à-vis firms with weak pricing power. The enhanced cash flow cushion translates into a lower likelihood of distress (which is generally followed by exit) in response to production cost shocks. Based on the above arguments, we reason that firms with high product market power will need to engage in less earnings management. Hence, we contend that product market power and earnings management can be viewed as substitutes. This leads us to our first hypothesis.

Hypothesis 1: Firms with greater product market pricing power relative to other firms in a specific industry will be associated with lower discretionary accruals management.

At the industry level, product market competition can play an important role in determining the degree of accruals management by the typical firm in that industry. It can be argued that greater product market competition in an industry, as measured by the industry structure, will lead to more earnings management because the cushion of supranormal profits in the form of Ricardian rents for typical firms in this industry is expected to be correspondingly smaller (see Peteraf, 1993). Therefore, along the lines of our preceding argument at the firm level, we correspondingly argue that, at the industry level, firms in more competitive industries are also expected to resort to greater degree of earnings management because they are less able to pass along an adverse cost shock to the 
consumers in that industry. Another argument that links firms in more competitive industries to earnings management is related to manager's career concerns and myopic managerial behavior. Accorindg to this argument the more competitive the product market is, the greater the manager's career concenrns which will increase the maanger's propensity to manage earnings (e.g. Fama, 1980; Rotemberg and Scharfstein, 1990; Hermalin and Weisback, 2007). In a related accounting study, Karuna (2007) shows that firms in more competiive industries monitor their CEOs more closely than in less competitive industries.

Another argument that can suggest a relationship between competition and reporting quality is the proprietary costs present in competitive industries. Competition can induce more opaqueness in earnings that helps firms to conceal the economic shocks they experience from their competitors. For instance, firms with higher demand may strategically determine that it is best to withhold such information through earnings management because by doing so they hold back the signal of good future prospects from rival firms. Verrecchia (1983) proposes that due to the adverse impact from disclosure, firms in industries characterized by intense product market competition prefer less informative disclosure policies to reduce predatory threats from rivals. Further, Fan and Wong (2002) show that limiting the information flow allows insiders to sidestep the competition. Thus, it can be argued that earnings management can act as a mechanism through which the firm strategically withholds valuable information from rivals thereby reducing the transparency of financial statements. Based on the above set of arguments we propose the following hypothesis.

Hypothesis 2A: Firms in more competitive industries will be associated with greater discretionary accruals management.

Product market competition has been shown to serve as an external disciplinary corporate governance mechanism aligning the interests of the managers with shareholders (Hart, 1983; Grullon and Michaely, 2007; Shleifer and Vishny, 1997), which in turn provides an alternate mechanism linking industry competition to earnings management. Recent empirical evidence seems 
to support the idea that product market competition provides incentives for managers to be more closely aligned with shareholders' interests (e.g. Giroud and Mueller, 2011). Prior empirical research also shows that a weak disciplinary environment allows managers to engage in more earnings manipulation (see, for example, Becker, DeFond, Jiambalvo, and Subrahmanyam, 1998; Bowen, Rajgopal, and Venkatachalam, 2008; Guidry, Leone, and Rock, 1999). Klein (2002) argues that the internal governance environment is an important determinant of the level of earnings management. She finds that strong internal governance is associated with less pronounced abnormal accruals.

By the same token, it can be argued that external disciplinary pressures may limit how much firms can manage reported earnings. Allen and Gale (2000) posit that competition between firms is a more effective disciplinary mechanism than either internal governance mechanisms or external monitoring mechanisms, such as the market for corporate control. If competitive pressures are more effective at monitoring and disciplining management, then firms operating in such environments will exhibit lower propensity to manage reported earnings. Using the same logic, Balakrishnan and Cohen (2011) argue that industry concentration plays a disciplinary role in alleviating the agency problem of financial accounting misreporting. Based on the above arguments we propose the following hypothesis:

Hypothesis 2B: Firms facing greater competitive pressure from product markets will be associated with lesser degree of discretionary accruals management.

\section{Sample and measurement of variables}

\subsection{Sample formation}

Our sample selection process starts by including all firms in the COMPUSTAT database during the period 1987-2009. The beginning of our sample period is determined by the availability of the key variable, cash flow from operations, to estimate accruals. We also require that the sample firms be covered in the Center for Research in Securities Prices (CRSP) monthly files and trade on 
NYSE, AMEX, and NASDAQ exchanges and whose securities correspond to common equity (CRSP share code between 10 and 19). We drop firms that changed their fiscal year-end during the sample and confine our analysis to firms based in the US. To remove the effect of small firms, we restrict our attention to firms that have at least $\$ 1$ million in sales and assets. We define each firm's industry based on Fama-French 49 industry classification. We drop financials ("Banks", "Trading", "Insurance", and "Real Estate") from our sample because of the differential nature of their financial statements and also eliminate utilities because they are subject to regulations. Finally, we delete all firm-years with inadequate data to calculate discretionary accruals (as defined below) or any of the variables needed to estimate the cross-sectional modified Jones model with Kothari et al.'s (2005) adjustment for firm performance. The above selection criteria yield a maximum sample of 43,628 firm-year observations representing 6,019 unique firms.

\subsection{Measuring product market power and industry-level competition}

\subsubsection{Intra-Industry Measure of Market Power}

\section{Firm-specific product market pricing power}

Following much of the industrial organization literature (e.g. Lindenberg and Ross, 1981 and Domowitz et al. 1986), we construct our product market pricing power measure based on the Lerner Index (LI) (see Lerner, 1934) which is also referred to as the price-cost margin scaled by sales. It is calculated as follows:

$$
P C M=L I=\frac{\text { Sales }-C O G S-S G \& A}{\text { Sales }}
$$

where Sales is COMPUSTAT variable SALE, cost of goods sold, COGS, is COMPUSTAT variable COGS, and sales, general and administrative expenses, SG\&A, is COMPUSTAT variable XSGA. This measure excludes depreciation, interest, special items and taxes. We use operating income before depreciation (COMPUSTAT variable OIBDP) to calculate price-cost margin when there is 
missing data for the above items.

Although the price-cost margin has been used to capture a firm's product market power, this measure does not, however, isolate the firm-specific factors that influence product market pricing power from industry-wide factors. This metric can fluctuate due to industry-specific attributes that are unrelated to a firm's market pricing power. Given that we are interested in examining the link between earnings manipulation and a firm's product market power within an industry, we use an industry-adjusted Lerner Index to capture firm-specific product market power. To do so, we compute the value-weighted industry-adjusted Lerner Index (Market Power), which is the difference between the firm's price-cost margin and the sales-weighted price-cost margin of the all firms within an industry and is described by the following equation.

$$
\text { Ma rket Po wer }=L I_{i}-\sum_{i=1}^{N} \omega_{i} L I_{i}
$$

where $\mathrm{LI}_{\mathrm{i}}$ is the Lerner Index (defined in equation (1) above) for firm $i, \omega_{i}$ is the proportion of sales of firm i to total industry sales where industry is defined as the firm's industry as per Fama-French 49 Industry Classifications, and $\mathrm{N}$ is the total number of firms in the industry (using the entire universe of firms in that industry available in the COMPUSTAT database). This modified Lerner Index measure captures purely the intra-industry market power of a firm, therefore purging the effects of industry-wide factors common to all firms in a specific industry. Further, this adjustment addresses the fact that different industries have structurally different profit margins due to factors unrelated to intra-industry differences in market power of the firms.

\subsubsection{Industry-level measures of competition}

\section{Industry Lerner Index}

Following Cremers, Nair and Peyer (2007), we use the industry median price-cost margin to capture industry competitiveness. They argue that higher profit margins in an industry reflect less 
intense competitive environment and that thin margins are associated with greater competitive pressures since adverse input price shocks could not be passed through to customers through output price hikes.

\section{Number of firms in the industry}

One of the main factors that shape the intensity of rivalry in an industry is the number of firms in a sector (Porter, 1980) where larger number of firms in the industry magnifies competition. Balakrishnan and Cohen (2011) argue that since firms in an industry compete not only for economic profits but also for funds from capital markets, the number of firms in an industry reflects competition for limited funds. In the presence of greater competition, they posit that firms in highly populated industries will provide higher quality of information, and hence earnings management will be lower. An opposing argument based on evidence that managers inflate earnings prior to seasoned equity offerings, initial public offerings and stock-financed acquisitions (Teoh, Welch and Wong, 1998; Rangan, 1998; Erickson and Wang, 1999) implies that the greater the competition for external funding the greater the earnings management. Hence, the impact of number of firms in an industry on earnings management is an empirical issue. Following Cremers, Nair and Peyer (2007) and Balakrishnan and Cohen (2011), we employ $1 / \mathrm{n}$ where $\mathrm{n}$ is the number of firms in an industry as an alternative proxy for competition.

\section{Industry Concentration}

Industry concentration is typically used to measure competition for industry-level analysis (as opposed to firm-level product pricing power). Industry concentration is usually measured by Herfindahl-Hirschman Index (HHI). Although HHI, as a measure of concentration, is fairly well rooted in industrial organization theory (Curry and George, 1983; Tirole, 1988, pp. 221-223), doubts exist that it could imply both high and low competition. Recent research suggests that when market structure is assumed to be endogenous, it is unclear whether low values of concentration capture 
low or high competition, especially in cross-industry analyses (e.g., Demsetz, 1973; Symeonidis, 2002; Raith, 2003; Aghion et al., 2005). Therefore, a tension exists on the topic of whether industry concentration (competition) is associated with low or high degree of industry competition and how this competition acts as an external governance mechanism in influencing corporate earnings management.

Because of the recognized shortcomings associated with the traditional HerfindahlHirschman Index, we measure industry concentration considering the aggregate sales of the four largest firms in the industry as an alternative proxy for industry competition (see Cremers, Nair, and Peyer, 2007). Specifically we measure concentration as the fraction of entire industry sales that is accounted for by the aggregate sales of the four largest firms in the industry. This measure, common in empirical industrial organization literature, is routinely applied by government agencies. Because we are using three different proxies for industry competition that are unrelated to HHI, our conclusions from the industry level analysis should not be affected by the issues surrounding HHI as a measure of competition.

\subsubsection{Measurement of earnings management}

To estimate accruals management, we have to distinguish between two types of accruals: nondiscretionary accruals that are indispensible accounting adjustments and discretionary accruals made at the discretion of managers to manipulate earnings. Because not all accruals are the result of opportunistic manipulation by managers, we first have to estimate non-discretionary accruals and extract it from total accruals to derive the discretionary component.

Following previous studies we use the modified version of the Jones model (see e.g., Jones, 1991; Dechow, Sloan and Sweeney, 1995) to capture discretionary accruals (DA). Hribar and Collins (2002) point out the concerns associated with estimating accruals using the balance sheet approach. Therefore to estimate discretionary accruals more accurately, we use the cash flow data from the 
statement of cash flow in COMPUSTAT. This is currently the accepted and popular methodology for capturing accruals management in the literature (see e.g. Bartov, Gul and Tsui, 2001; Kothari, Loutskina, and Nikolaev, 2006).

This methodology derives discretionary accruals in two stages. First, total accruals variable (defined as the difference between net income and cash flows from operations) is regressed on key variables that are expected to influence it. Specifically, we estimate nondiscretionary accruals from cross-sectional regressions of total accruals (TACC) on changes in sales minus change in receivables, property, plant, and equipment (PPE), and lagged return on assets (ROA) for each of the FamaFrench industry classification in every fiscal year. We include lagged return on assets (ROA) as an additional regressor to control for the effect of performance on a firm's accruals (Kothari et al., 2005; Ronen and Yaari, 2008). We run the following cross-sectional OLS regression using FamaFrench industry code to estimate the coefficients $\alpha_{1}, \alpha_{2}$, and $\alpha_{3}$. These cross-sectional regressions require a minimum of 15 observations for each year and Fama-French industry combination.

$$
\frac{T A_{i t}}{A_{i \neq 1}}=\alpha_{1} \frac{1}{A_{i \neq 1}}+\alpha_{2}\left(\frac{\Delta R E V_{i t}}{A_{i \neq 1}}-\frac{\Delta A R_{i t}}{A_{i \neq 1}}\right)+\alpha_{3} \frac{P P E_{i t}}{A_{i \neq 1}}+\alpha_{4} \frac{\text { Net Income }_{i \neq 1}}{A_{i \neq 1}}+\varepsilon_{i}
$$

where $\mathrm{i}$ indexes firms, $\mathrm{t}$ indexes time, $\mathrm{TA}_{\mathrm{it}}$ equals Net Income (COMPUSTAT variable NI) minus cash flow from operations (COMPUSTAT variable OANCF), $\triangle \mathrm{REV}_{\text {it }}$ is the changes in sales (COMPUSTAT variable SALE), $\triangle \mathrm{AR}_{\mathrm{it}}$ is the change in Receivables (COMPUSTAT variable RECT) and PPE is the total property, plant, and equipment (COMPUSTAT variable PPEGT). All these variables are scaled by lagged value of assets (COMPUSTAT variable AT). We use the estimated coefficients $\hat{\alpha}_{1}, \hat{\alpha}_{2}, \hat{\alpha}_{3}$, and $\hat{\alpha}_{4}$ to compute discretionary accrual as follows:

$$
D A_{i t} \equiv \varepsilon_{i t}=\frac{T A_{i t}}{A_{i t-1}}-\left(\hat{\alpha_{1}} \frac{1}{A_{i \neq 1}}+\hat{\alpha}_{2}\left(\frac{\Delta R E V_{i t}}{A_{i \neq 1}}-\frac{\Delta A R_{i}}{A_{i \neq 1}}\right)+\hat{\alpha_{3}} \frac{P P E_{i t}}{A_{i \neq 1}}+\hat{\alpha}_{4} \frac{\text { Net Incone }_{i \neq 1}}{A_{i \neq 1}}\right)
$$


Large values of discretionary accruals are generally construed to indicate earnings management. Because discretionary accruals could be positive (when firms inflate earnings) or negative (when in good years managers conceal earnings for future use), both positive and negative discretionary accruals capture earnings management. We winsorize the variables at 1 percent and 99 percent levels to reduce the influence of outliers. It is important to note that because we are using Kothari et al. (2005) methodology of calculating discretionary accruals, which controls for firm performance, the relationship between accruals and Market Power is unlikely to be mechanical.

\subsubsection{Sample description}

Table 1 presents several focus-relevant salient summary statistics for our sample. We classify the descriptive statistics into four categories based on firm characteristics, product market power measures, industry competition measures and accruals management metric. All the variables are defined in Appendix 1. The sample firms have a mean (median) market capitalization of $\$ 2,038$ million (\$193 million). The median sample firm has a sales volatility of 13.6 percent.

Next we present in Table 1 summary statistics for our measure of product market power. The median $\mathrm{LI}_{\mathrm{IA}}$ for our sample is -3.44 which is comparable to that reported by Gaspar and Massa's (2006) (-5.8) for a different sample period. Regarding industry competition measures, the median of median industry Lerner Index is $9.44 \%$ while the median number of firms in an industry is about 79 . The median market share of the four largest firms in an industry is $5.17 \%$. Finally, the median absolute level of discretionary accruals for our sample is 5.5 percent of lagged assets, which is similar to prior studies.

Table 2 presents the Pearson correlations between the variables used in the analysis. The correlations between firm characteristic control variables (Leverage, Size, Book-to-market, Growth and Volatility of sales), although significant, tend to be small in magnitude. One notable observation regarding the relationship between the various test variables on product market pricing power and 
industry competition is the lack of significant correlation between Market Power and Concentration indicating that they capture two different aspects of competition - one at the firm-level and the other at the industry level. This validates our premise that intra-firm product market pricing power and industry concentration capture distinct aspects of a firm's competitive environment. In line with prior research, we find that absolute discretionary accrual is positively correlated with Growth, Leverage, and Volatility of sales.

\section{Empirical findings}

\subsection{Univariate analysis}

In Table 3, we sort firms, in each fiscal year in quintiles on the basis of market power and compute their average level of absolute discretionary accrual. For each market power quintile, we then calculate the time-series mean and median absolute level of discretionary accruals for the whole sample and then separately for positive and negative absolute accruals. We also test for the mean difference in accruals between the extreme quintiles.

In support of our first hypothesis (H1), these univariate results show that the absolute level of discretionary accruals declines significantly as market power increases. Specifically, the median absolute level of discretionary accruals of 13.3 is the highest for the lowest market power group (quintile 1), while the accrual measure for firms with the highest market power (quintile 5) is almost half that amount at 7.3 of lagged assets. The difference between the mean absolute levels of accruals for these two quintiles is highly statistically significant $(<1 \%$ level). The progression of accruals indicates that it is monotonically decreasing in firm's market power. The result is robust to using the median values or a market power metric that is not industry adjusted. All our conclusions remain robust to the use of a normalized market power variable, measured as the average of Market Power (industry-adjusted Lerner Index) over the preceding three years. Overall, the findings are consistent with the notion that lack of market power makes it more likely that a firm's management will engage 
in earnings management, whereas firms that enjoy a more powerful pricing power in their product market are less likely to do so.

In the remaining columns of Table 3 we provide the absolute positive and negative accruals separately. The results confirm the findings from the total sample indicating that firms with greater market power engage in less earnings manipulation whether it is upward or downward management and the differences between the two extreme quintiles are statistically significant.

\subsection{Multivariate analysis}

In this section we examine the relationship between absolute discretionary accruals scaled by lagged assets (Abs Disc Accruals) and product market pricing power (Market Power) in a multivariate setting, while controlling for the standard salient determinants of discretionary accruals using firm level characteristics previously identified in the literature, such as the growth rate in assets (Growth), market-to-book ratio (Market-to-book) and volatility of sales (Volatility), firm size (Size), and Leverage. We estimate various configurations of the following model:

$$
\begin{aligned}
\text { Abs Disc Accruals }_{\mathrm{jt}}= & \beta_{0}+\beta_{1} \text { Market }_{\text {Power }}+\beta_{2 \mathrm{t}} \text { Growth }_{\mathrm{jt}}+\beta_{3} \text { Market-to-book }_{\mathrm{jt}} \\
& +\beta_{4} \text { Volatility }_{\mathrm{j} \mathrm{t}}+\beta_{5} \text { Size }_{\mathrm{j} \mathrm{t}}+\beta_{6} \text { Leverage }_{\mathrm{jt}}+\varepsilon_{\mathrm{j}}
\end{aligned}
$$

We include year and industry dummies to control for business cycle effects and differences across industries, respectively. All the standard errors in the regressions are clustered at the firm level. The regression estimates are presented in Table 4.

\section{Control variables}

We control for standard firm characteristics. We include two proxies for firm growth because such firms may face greater capital market pressure to manipulate their earnings (Lee et al. 2006), namely, growth and market-to-book ratio. Growth is the change in assets scaled by one year lagged assets. Market-to-book is the ratio of market capitalization to the book value of the firm. We 
control for firm size since larger firms facing more scrutiny from investment professionals as well as more political costs are less likely to engage in accruals management. Size is the natural logarithmic transformation of market capitalization. To calculate the Volatility of sales measure, we obtain the standard deviation of sales from the preceding three-year period scaled by one year lagged assets. For robustness, we also utilize two additional measures of volatility, namely, volatility of cashflows, and volatility of return on assets (ROA). The subscripts $i$ and $t$ refer to firm and year respectively.

Using a large sample of 43,628 firm-year observations we establish for the first time a strong link between product market power of firms and their degree of discretionary accruals management. This finding in the baseline regression, Model 1, is robust to alternative specification that includes additional volatility measures such as volatility of cash flows and volatility of return on assets. For instance, the coefficient on this variable in Model 1 is -0.451 , which is significant at better than the 1 percent level. To gauge the economic significance of this finding, we measure the impact of onestandard deviation movement in the Market Power metric from its median value and find that this increases discretionary accruals by almost 14 percent of lagged assets. In unreported results, we also find a strong association when the Market Power variable is not industry-adjusted. Our results, which provide compelling empirical evidence in support of Hypothesis 1, imply that firms with low product market power place importance on the predictability of their earnings. This empirical finding also implies that lack of external disciplinary forces (for firms with high market power) does not encourage such firms to engage in greater manipulation of earnings; hence, these firms' financial statements are more transparent, of higher quality, and stand to be more informative than their industry counterparts that have not been able to harness the pricing power by creating competitive advantage that these firms enjoy.

\subsubsection{Accounting for the influence of governance mechanisms}


In Models 2 through 6, we introduce different variables to control for the possibility that various governance mechanisms may be behind the change in discretionary accruals. In Models 2 and 3, we control for two external forms of monitoring such as institutional holdings and analysts coverage, respectively. The private information search activities and scrutiny by investment professionals, such as institutional investors and analysts serve to diminish informational asymmetry as well as reduce the propensity of the firm to engage in earnings management. In support of that argument, Datta, et al. (2011a) document a significantly negative association between institutional holdings and earnings accruals. In a related vein, Balakrishnan and Cohen (2011) find a negative relation between institutional holdings and the frequency of earnings restatements while Yu (2008) documents a similar relationship between analyst coverage and accruals.

Prior research has also established that institutional holdings and the intensity of analysts' following plays a key role in monitoring the firm as well as in disseminating information (Lang and Lundholm, 1996). To the extent that the monitoring of investment professionals substitutes for competitive pressures, the relevance of our Market Power variable may diminish in the presence of external monitoring from investment professionals. The results in Models 2 and 3 show that the monitoring from larger institutional holdings significantly diminishes discretionary accruals. Although greater analysts coverage of the firm also reduces the amount of earnings management, this reduction is not statistically significant at conventional levels ( $\mathrm{p}$-value 0.11). Importantly, in both cases, the significance of our Market Power variable is maintained indicating that the effect of Market Power is in addition to that from monitoring by institutional investors and analysts.

In Model 4 we control for internal governance by utilizing the Gompers, Ishii and Metrick (2003) GIM Index, which measures shareholder rights based on 24 provisions. Because this index is updated infrequently and it is available only for later years for part of our sample period, our tests using this measure apply to a subset of our sample firms. We follow the literature by assuming the 
last available value when the index is between two updates. A high GIM Index represents lower shareholder rights. The coefficient for this variable is insignificant while the result for our test variable, Market Power, remains robust to the inclusion of this metric. ${ }^{3}$

\subsubsection{Accounting for the influence of executive compensation}

Some recent work has demonstrated empirically that high equity-based compensation can aggravate managerial incentives by encouraging earnings manipulation. For instance, studies have shown that managers are found to manipulate earnings to influence their bonuses (Guidry et al. 1999) and to gain from insider sales of shares (Beneish and Vargus 2002) while Bergstresser and Philippon (2006) report that earnings management is more pronounced in firms where a large fraction of CEO compensation is tied to stock and option holdings. We test the degree to which internal incentives affect the influence of competitive advantage in the product market, by including the equity-based compensation as a fraction of total CEO compensation package in Model 6. Equity-based compensation $(C E O E B C)$ is calculated as the sum of the value of stock options granted and restricted stockholdings of the CEO divided by total compensation. The coefficient estimate on $C E O E B C$ although positive is insignificant. The findings indicate that our focus variable, Market Power, is robust to the inclusion of this variable.

\subsubsection{Accounting for the influence of the firm's information environment}

Previous work has established a negative link between information asymmetries and the firm's bid-ask spread (Leuz and Verrechia, 2000). Firms with greater information asymmetries (higher bid-ask spread) have greater incentives to manage earnings to reduce the adverse impact of information asymmetries. In Model 7 we control for firm's information environment by

\footnotetext{
${ }^{3}$ In an unreported regression specification, we employ the E-Index proposed by Bebchuk, Cohen and Ferrel (2004) that is based on 6 of the 24 provisions in the GIM index. Again, our results are robust to the inclusion of this external governance variable.
} 
incorporating the bid-ask spread of the firm's stock. Following the literature on bid-ask spread, we compute Spread as the average of the daily closing (ask price-bid price)/closing price for each firm in each fiscal year. The positive Spread coefficient is significant with p-value of 0.02 . Again, the inclusion of this variable in Model 7 does not influence the relevance of our test variable, Market Power.

Overall, our firm characteristic control variables in the seven regression models presented in Table 4 consistently indicate that firms that utilize accruals management tend to be smaller firms, with less leverage and higher growth and volatility. Minton and Schrand (1999) find that firms with higher cash flow volatility face higher costs of external financing. Thus, our finding of a positive relation between cash flow volatility and accrual implies that firms with more costly external financing are more likely to manipulate reported earnings. Additionally, Maksimovic and Pichler (2001) argue that firms that utilize innovative new technologies incur larger disclosure costs. This reasoning implies that firms with high market-to-book ratio are more concerned about divulging private information through their financial statements and thus strategically manage earnings more. Our finding of positive and significant coefficients on Market-to-Book confirms this conjecture.

Our study complements findings reported by Balakrishnan and Cohen (2011) who examine the association between industry competition and the frequency of accounting restatements. While the findings of Balakrishnan and Cohen are informative, the restatement of earnings is a relatively infrequent event, and oftentimes is the product of a deliberate and/or illegal attempt by managers to misrepresent the financial condition of the firm to outsiders which is met by large adverse market valuation consequences (Palmrose, Richardson, and Scholz, 2004). Earnings management, on the other hand, is much more prevalent and is not generally associated with negative reputational effect on the firm. 
Our method of calculating accruals, which adjusts for firm performance, makes it unlikely that the relationship that we observe between accruals and the industry-adjusted Lerner Index (Market Power) is mechanical. Further, a negative accrual does not necessarily imply a low price-cost margin nor does a positive accrual imply the opposite. For example, Lee et al. (2010) find that large negative DA and low profitability lead to more frequent CFO dismissals than large negative DA and high profitability.

Overall, the results presented in this section are consistent with the notion that lack of product market pricing power makes it more likely that a firm's managers will engage in earnings management, whereas firms that enjoy a more powerful pricing power in their product market as a manifestation of their competitive advantage are less likely to do so. Our findings also support the view that firms with strong product market positions are less likely to manipulate reported earnings because of better abilities to bear idiosyncratic cost shocks.

\subsubsection{Multivariate results for positive and negative discretionary accruals}

In Panels $\mathrm{A}$ and $\mathrm{B}$ of Table 5, we replicate the analysis of Table 4 after partitioning the firms that engage in positive and negative discretionary accruals separately to verify whether the impact of product market power on accruals is symmetrical. The results in Table 5 utilize the same firm characteristic control variables; however, the coefficients on these control variables (which are similar to those obtained earlier) are omitted from the table for parsimony. The coefficient estimate on Market Power in the baseline model, Model 1, is positive and significant whether the absolute discretionary accruals are positive (Panel A) or negative (Panel B) indicating that firms with weaker product market positions are more likely to engage in both types of earnings management.

The coefficients in Model 2 from both panels reveal that institutional holdings have a dampening effect on inflationary and deflationary earnings management. Interestingly, in Model 3, the influence of analysts' coverage on managerial behavior is asymmetrical where higher analyst 
following diminishes the engagement in positive accruals while increasing negative accruals. Akin to findings from Table 3, here also the significance of the Market Power variable remains robust to the inclusion of institutional holdings and analysts coverage.

The results for Model 4, which controls for managerial entrenchment using GIM Index, also indicate asymmetry in managerial behavior regarding earnings management. The greater managerial entrenchment (higher GIM Index), the more likely the firm to inflate earnings (as shown in Panel A) and less likely to deflate earnings (Panel B). Both of these associations are statistically significant. Confirming earlier results for the whole sample, in Model 5, the internal incentives from CEO equity pay do not play a role in earnings management. In the last model (Model 6), which includes Spread, the coefficient is significantly positive only in Panel A indicating that the greater the information asymmetry, the more likely managers will inflate earnings. In all models, our focus test variable is robust to the inclusion of these external and internal governance mechanisms in support of the view that none of these governance factors can be considered substitutes for product market pricing power at the firm level within an industry.

\subsubsection{Additional robustness checks}

To test the robustness of our results, we also use the preceding three-year average (i.e., normalized) Market Power. Using the three-year average accomplishes two objectives. First, a higher Market Power over a three-year period reflects a more sustainable competitive advantage than that from one year, and second, there is less likelihood of the association between our product market measure and accruals from being spurious. All our results in this study and conclusions remain robust to the use of the normalized variable. Further, it is worth noting that when we employ alternative measures to capture competitiveness at the industry level (in the next section), our results mirror what we obtain at the firm level. This confirms that our results are not driven by possible mechanical connection between our measure of pricing power and discretionary accruals. Finally, to 
account for conglomerates, we repeat all our analyses with and without multi-segment firms and find that all our results are robust to this distinction. In another specification, when we include a dummy variable to control for multi-segment firms, the results are qualitatively the same.

\subsection{Multivariate analysis of the influence of industry competition on earnings management}

In this study we have underscored and articulated the distinction between firm-level pricing power vis-à-vis the industry rivals and industry-level competitiveness. Consequently, we have also identified the appropriate measures to capture these different dimensions of competition at the firmlevel and for the industry. Recently, Datta, Iskandar-Datta and Sharma (2011b) link product market pricing power and industry concentration to analysts' earnings forecast.

In Table 6 we examine how industry competitiveness influences earnings management in that industry. Hence, the analysis is conducted at the industry level. As described earlier, three different industry-wide competitiveness metrics are utilized: industry median Lerner Index, the inverse of the number of firms in the industry, and industry concentration. We include the same firm characteristic variables used in preceding firm level regressions as control variables, except in this case the variables reflect the industry medians. Standard errors are adjusted for industry-level clustering. Various configuration of the following general regression model are estimated at the industry level:

$\begin{aligned} \text { Abs Disc Accruals }= & \beta_{0}+\beta_{1} \text { Industry-level Competition }+\beta_{2} \text { Growth }+\beta_{3} \text { Market-to-book }+ \\ & \beta_{4} \text { Volatility }+\beta_{5} \text { Size }+\beta_{6} \text { Leverage }+\varepsilon\end{aligned}$

We control for business cycle effects by including year dummies in the regression models. In Table 6 (Panel A) we report the results for the total sample while Panel B displays the regression estimates for partitioned samples based on the sign of the accruals (positive for inflationary earnings management and negative for deflationary earnings management). Model 1 (Panel A), which uses Industry LI (industry median Lerner Index) as the focus explanatory variable, shows a significantly 
negative association with discretionary accruals. This result indicates that industry-level competitiveness is inversely related to the degree of accruals management in that industry. Given that industries characterized by thin margins are associated with greater competitive pressure, the results imply that more competitiveness leads to more earnings management, consistent with the findings obtained when using firm-specific market power. Consistent with Model 1, the negative and significant coefficient estimate in Model 2 for Concentration also indicates that the less the competition in an industry, the less the degree of accruals management in that industry. Testing the relevance of the inverse of the number of firms in an industry to accruals in Model 3 also reveals that greater competitive pressures lead to more accruals.

Panel B of Table 6 presents results for absolute value of positive and negative accruals separately. The findings confirm that the results in Panel A hold for the two categories of accruals for each measure of industry competition. However, while the firms operating in a competitive, heavily-populated, industry show greater propensity to inflate earnings with a significantly negative coefficient (Model 5), the coefficient estimate in Model 6, although negative, is not statistically significant at conventional levels indicating lack of a link between negative accruals and number of firms in the industry.

Overall, our analysis at the industry level, which is in line with hypothesis $2 \mathrm{~A}$, supports the view that greater competition in an industry leads to higher degree of earnings management for the average firm in that industry as compared to firms in industries with lower competitive pressure

\section{Conclusions}

This study adds an important new dimension to the earnings management literature by establishing a link between product market power of firms and their degree of earnings management. Specifically we establish a link between (a) firm level product market pricing power and the degree to which firms manage their reported earnings and (b) industry competitiveness and 
the degree of earnings management for the industry. All our findings are highly robust to alternative measurements of variables, as well as controlling for (a) internal and external disciplinary governance mechanisms, (b) executive compensation, and (c) the firm's information environment. Based on a comprehensive sample of 43,628 firm-year observations during the period spanning 1987-2009, we document that product market power of firms is inversely related to discretionary accruals management. Our findings are consistent with the notion that lack of product market pricing power makes it more likely that a firm's managers will engage in earnings management, whereas firms that enjoy a more powerful pricing power in their product market as a manifestation of their competitive advantage are less likely to do so. These results are maintained for both inflationary and deflationary earnings management.

By identifying product market power as a motive behind earnings management, we identify conditions in which managers' incentives to manage earnings are likely to be more aggressive. This suggests that earnings reported by firms with weaker product market pricing power or firms in competitive industries are relatively less reliable because they are prone to greater earnings manipulation than their counterparts with greater pricing power and firms in less competitive industries. This study contrasts with much of the previous literature which focuses on documenting earnings manipulations that "games" the capital markets prior to a certain event such as SEO or to boost executive bonuses.

Overall, the knowledge derived from this study provides additional tools to assess the degree of earnings management by firms and hence their quality of financial reporting, thus enabling standard setters, financial market regulators, analysts and investors to make more informed legislative, regulatory, resource allocation, and investment decisions. 


\section{References}

Aghion, P., N. Bloom, R. Blundell, . R. Griffith,. and P. Howitt, 2005, Competition and innovation: An inverted-U relationship, The Quarterly Journal of Economics 120, 2, 701 - 728.

Allen, F., and D. Gale, 2000, Corporate governance and competition, published in Corporate governance: Theoretical and empirical perspectives, edited by X. Vives, Cambridge University Press, 23-94.

Mark Bagnoli, M., and S. Watts, 2010, Oligopoly, Disclosure, and Earnings Management, The Accounting Review 85, 1191-1114.

Balakrishnan, K., and D. Cohen, 2011, Product market competition, financial accounting misreporting and corporate governance: evidence from accounting restatements, Working Paper, Stern School of Business, New York University.

Bartov, E., F. Gul, and J. Tsui, 2001, Discretionary-accrual models and audit qualifications. Journal of Accounting and Economics 30, 421-452.

Bebchuk, A., A. Cohen, and A. Ferrell, 2004, What Matters in Corporate Governance?, Review of Financial Studies 22, 783-827.

Becker, C., M. DeFond, J. Jiambalvo, and K. Subramanyam, 1998, The effect of audit quality on earnings management, Contemporary Accounting Research 15, 1-24.

Beneish, M., and M.Vargus, 2002, Insider trading, earnings quality, and accrual mispricing, The Accounting Review 77, 755-791.

Bergstresser, D., and T.Philippon, 2006, CEO incentives and earnings management, Journal of Financial Economics 80, 511-529.

Bowen, R., S. Rajgopal, and M. Venkatachalam, 2008, Accounting discretion, corporate governance and firm performance, Contemporary Accounting Research 25 (2), 351-405.

Collins, D., and P. Hribar, 2000, Earnings-Based and Accrual-Based Market Anomalies: One Effect or Two? Journal of Accounting and Economics 29, 101-124.

Cremers, K., V. Nair and U. Peyer, 2007, Takeover defenses and competition, ICF Working Paper No. 07-02, Yale University.

Curry, B., and K. George, 1983, Industrial Concentration: A Survey, The Journal of Industrial Economics, 31, 203-255.

Dalia, M., and J. Park, 2009, Market Competition and Earnings Management, Working Paper, SSRN.

Datta. S., M. Iskandar-Datta and V. Sharma, 2011a, Idiosyncratic volatility, earnings management and stock price informativeness, Working Paper, Wayne State University. 
Datta. S., M. Iskandar-Datta and V. Sharma, 2011b, Product market pricing power, industry concentration and analysts' earnings forecasts, Journal of Banking and Finance 35, 1352-1366.

Dechow, P., R. Sloan, and A. Sweeney, 1995, Detecting earnings management, The Accounting Review 70,193-226.

Dechow, P., R. Sloan, and A. Sweeney 1996, Causes and consequences of earnings manipulation: an analysis of firms subject to enforcement actions by the SEC, Contemporary Accounting Research $13,1-36$.

Demsetz, H., 1973, Industry structure, market rivalry, and public policy, Journal of Law and Economics 16, 1-10.

Domowitz, I., R. Hubbard and B. Petersen. 1986, Business cycles and the relationship between concentration and price-cost margins, RAND Journal of Economics 17,1-17.

Erickson, M., and S.Wang, 1999, Earnings management by acquiring firms in stock for stock mergers, Journal of Accounting and Economics 27,149-176.

Fama, E. F., 1980, Agency Problems and the Theory of the Firm, Journal of Political Economy 88, 288-307.

Fan, J., and T. Wong, 2002, Corporate ownership structure and the informativeness of accounting earnings in East Asia. Journal of Accounting and Economics 33, 401-425.

Gaspar, J., and M. Massa, 2006, Idiosyncratic volatility and product market competition, Journal of Business 79, 3125-3152.

Giroud, X., and H. Mueller, 2011, Corporate Governance, Product Market Competition, and Equity Prices, Journal of Finance 66, 563-600.

Gompers, P., J. Ishii, and A. Metrick, 2003, Corporate governance and equity prices, Quarterly Journal of Economics 118,107-155.

Graham, J., C. Harvey, and S. Rajgopal, 2005, The economic implications of corporate financial reporting, Journal of Accounting and Economics 40, 3-73.

Grullon, G., and R. Michaely, 2007, Corporate payout policy and product market competition, Working Paper, Rice University.

Guidry, F., A. Leone, and S. Rock, 1999, Earnings-based bonus plans and earnings management by business unit managers. Journal of Accounting and Economics 26, 113-142.

Hart, O., 1983, The Market Mechanism as an Incentive Scheme. The Bell Journal of Economics 14, 366-382.

Haushalter, D., S. Klasa, and W. F. Maxwell, 2006, The influence of product market dynamics on a 
firm's cash holdings and hedging behavior, Journal of Financial Economics 84, 797-825.

Healy, P., and J.Wahlen, 1999, A review of the earnings management literature and its implications for standard setting, Accounting Horizons 13, 365-383.

Hermalin, B., 1992, The effects of competition on executive behavior, RAND Journal of Economics 23, 350-365.

Hermalin., B. and M. Weisbach, 2007. Transparency and Corporate Governance, NBER Working Papers 12875, National Bureau of Economic Research, Inc.

Holmstrom, B., 1982, Moral hazard in teams, Bell Journal of Economics 13, 324-340.

Hribar, P., and D. Collins, 2002. Errors in estimating accruals: Implications for empirical research, Journal of Accounting Research 40, 105-134.

Jones, J., 1991, Earnings management during import relief investigations, Journal of Accounting Research 29, 193-228.

Karuna, C. 2007. Industry Product Market Competition and Managerial Incentives, Journal of Accounting and Economics, 43, 275-297.

Klein, A., 2002, Audit committees, board of director characteristics and earnings management, Journal of Accounting and Economics 33, 375-400.

Kothari, S., A. Leone, and C. Wasley, 2005, Performance matched discretionary accruals, Journal of Accounting and Economics 39, 161-197.

Kothari, S., E. Loutskina, and V. Nikolaev, 2006. Agency theory of overvalued equity as an explanation for the accrual anomaly, Working Paper (MIT Sloan School of Management).

Lang, M, and R. Lundholm, 1996, Corporate Disclsoure Policy and Analyst Behavior, The Accounting Review 71, 467-492.

Lee C., E. Lusk, and M. Halperin, 2010, CFO resignations: Their underlying performance and behavioural context. International Journal of Behavioral Accounting and Finance 1, 312-334.

Lee, C., L. Li, and Y. Heng, 2006. Performance, growth and earnings management. Review of Accounting Studies 11, 305-334.

Lerner, A., 1934, The concept of monopoly and the measurement of monopoly power. Review of Economic Studies 1, 157-175.

Lindenberg, E., and S. Ross, 1981. Tobin's q ratio and industrial organization, Journal of Business $54,1-32$.

Leuz, C., and R. Verrecchia. 2000. The economic consequences of increased disclosure. Journal of Accounting Research 38, 91-124. 
Maksimovic, M., and P. Pichler, 2001. Technological innovation and initial public offerings, Review of Financial Studies 14,: 459-494.

Markarian, G., and J. Santalo 2010, Product Market Competition, Information and Earnings Management, Working Paper, IE Business School.

Minton, B., and C. Schrand, 1999, The impact of cash flow volatility on discretionary investment and the costs of debt and equity financing, Journal of Financial Economics 54, 423-460.

Palmrose, Z., V. Richardson, and S. Scholz. 2004. Determinants of market reactions to restatement announcements. Journal of Accounting and Economics 37, 59-89.

Perry S., and T. Williams, 1994. Earnings management preceding management buyout offers, Journal of Accounting and Economics 18, 157-179.

Peteraf, M., 1993. The cornerstones of competitive advantage: A resource-based view. Strategic Management Journal 14,179-191.

Porter, M., 1980. Competitive strategy: Techniques for analyzing industries and competitors. New York: Free Press.

Raith, M., 2003, Competition risk and managerial incentives, American Economic Review 93, 14251436.

Rangan, S., 1998, Earnings management and the performance of seasoned equity offerings, Journal of Financial Economics 50, 101-122.

Rotemberg, J., and D. Scharfstein, 1990, Shareholder-Value Maximization and Product-Market Competition, Review of Financial Studies 3, 367-391.

Salop S., 1979, Strategic entry deterrence, American Economic Review 69,335-338.

Skinner, D., and R. Sloan, 2002, Earnings surprises, growth expectations, and stock returns or don't let an earnings torpedo sink your portfolio, Review of Accounting Studies 7, 289-312.

Symeonidis, G., 2002, The effects of competition: Cartel policy and the evolution of strategy and structure in British industry. Cambridge, MA: The MIT Press.

Teoh, H., I. Welch, T. Wong, 1998, Earnings management and the long-run performance of initial public offerings, Journal of Finance 53, 1935-1974.

Tirole, J., 1998, The Theory of Industrial Organization, ISBN: 978-0-262-20071-4.

Verrecchia, R., 1983, Discretionary disclosure, Journal of Accounting and Economics 5, 365-380.

Ronen, J., and V. Yaari, 2008, Earnings Management, Emerging Insights in Theory, Practice, and Research, Springer Series in Accounting Scholarship, Vol. 3. ISBN 978-0-387-25769-3. 
Yu, F., 2008, Analyst coverage and earnings management, Journal of Financial Economics 88, 245271. 
Appendix 1

Variable Definitions

Institutional holdings for each firm is measured as the aggregate shares held by all institutional investors as reported in the 13 -F quarterly files divided by the total number of shares outstanding. We assume that in institutional holdings remains unchanged in the intervening months till the subsequent quarter holdings data become available in 13-F quarterly files.

Number of Analyst is number of valid estimates used to compute mean monthly earnings forecast for each firm in IBES historical summary files. In regressions, we use $\log (1+$ num of analysts $) / 100$.

Spread is computed as average of the daily closing (ask price-bid price)/closing price for each firm in each fiscal year. This variable is divided by 100 for regressions.

CEO EBC is computed as the value of equity-based compensation (value of granted options and restricted stockholdings) to total CEO pay package.

Concentration is computed as the sum of 4 largest firms' sales as a fraction of aggregate sales of all firms that exist in the same industry in COMPUSTAT files in each fiscal year. We use Fama-French 49 industry classification to define an industry.

GIM Index is an index measuring shareholder rights devised by Gompers, Ishii, and Metrick (2003) incorporating 24 governance provisions and state antitakeover laws. Regression variable is $\mathrm{GIM} / 100$.

Growth is calculated as the change in total assets (COMPUSTAT item AT) scaled by one year lagged assets.

Leverage is computed as one year lagged total long-term debt (COMPUSTAT item DLTT) divided by total assets (COMPUSTAT item AT).

Market capitalization is computed as the product of number of shares outstanding and the market price of the share from CRSP monthly files.

Market Power calculated as Sales (COMPUSTAT item sale) less cost of goods sold (COMPUSTAT COGS) less sales, general and administrative expenses (COMPUSTAT item XSGA) divided by sales, which is then industry-adjusted by subtracting sales-weighted price-cost margin of all firms within an industry.

Median Industry Lerner Index is the median value of a firm's Lerner index in an industry in a fiscal year using all firms that exist in COMPUSTAT files. Lerner index for each firm is calculated as Sales (COMPUSTAT item sale) less cost of goods sold (COMPUSTAT COGS) less sales, general and administrative expenses (COMPUSTAT item XSGA). We use Fama-French 49 industry classification to define an industry. 
Number of firms in an industry is the actual number of all firms in COMPUSTAT files in an industry in a fiscal year. We use Fama-French 49 industry classification to define an industry.

Market-to-book is the ratio of market capitalization to the book value of the firm (COMPUSTAT item CEQ). Regression variable is $\log (1+$ market-to-book $) / 100$.

Size is the natural logarithm of market capitalization/1000 (in regressions).

Volatility of sales is calculated as the standard deviation of sales over the preceding three-year period scaled by one year lagged assets (COMPUSTAT data item AT). 
Table 1

Descriptive Statistics

This table reports summary statistics for some salient characteristics of our sample. We have categorized the descriptive statistics into four groups: firm characteristics, market power measure, industry completion measures, and accruals management metrics. The statistics are based on a maximum of 43,628firm-year observations drawn from the intersection of the COMPUSTAT and CRSP databases spanning the period 1987-2009 for firms meeting our data requirements. These represent 6,019 unique firms spanning 36 industries based on Fama-French 49 Industry classification. All other variables are as defined in Appendix 1.

\begin{tabular}{|c|c|c|c|c|}
\hline Variable & Obs. & Mean & Median & Std. Dev. \\
\hline \multicolumn{5}{|c|}{ FIRM CHARACTERISTICS } \\
\hline Market capitalization (in $\$$ millions) & 43,628 & 2037.70 & 192.77 & 8510.46 \\
\hline Asset growth rate & 43,628 & 17.20 & 6.43 & 57.39 \\
\hline Market-to-book ratio & 43,628 & 3.19 & 1.98 & 11.95 \\
\hline Volatility of sales & 39,675 & 0.211 & 0.136 & 0.244 \\
\hline Leverage & 43,508 & 15.81 & 10.74 & 17.00 \\
\hline Institutional Holdings (\%) & 41,176 & 43.65 & 41.53 & 29.79 \\
\hline Number of Analysts & 43,628 & 5.52 & 3.00 & 6.89 \\
\hline GIM Index & 13,109 & 9.03 & 9.00 & 2.76 \\
\hline Average Bid-ask Spread & 40,287 & 0.030 & 0.016 & 0.040 \\
\hline CEO Equity-based compensation (EBC) & 9,535 & 41.62 & 43.10 & 29.71 \\
\hline \multicolumn{5}{|c|}{ MARKET POWER MEASURE } \\
\hline Market Power (\%) & 40,258 & -12.20 & -3.44 & 37.65 \\
\hline \multicolumn{5}{|c|}{ INDUSTRY COMPETITION MEASURE } \\
\hline Median Industry Lerner Index ( $\%)$ & 36 & 8.39 & 9.44 & 14.17 \\
\hline Concentration of 4 largest firms in industry sales $(\%)$ & 36 & 7.05 & 5.17 & 5.86 \\
\hline Number of firms in an industry & 36 & 100.79 & 78.75 & 73.78 \\
\hline \multicolumn{5}{|c|}{$\begin{array}{l}\text { ACCRUALS MANAGEMENT } \\
\end{array}$} \\
\hline Discretionary accruals/Assets ${ }_{\mathrm{t}-1}$ & 43,628 & 9.18 & 5.50 & 12.49 \\
\hline
\end{tabular}


Table 2

\section{Correlation matrix of salient variables}

This table reports Pearson correlations of some salient focus-relevant characteristics of our sample. The statistics are based on maximum of 43,628 firm-year observations drawn from the intersection of the COMPUSTAT and CRSP databases spanning the period 1987-2009 for firms meeting our data requirements. See Appendix 1 for variable definitions. Bolded correlations denote significance at the $1 \%$ level.

\begin{tabular}{|c|c|c|c|c|c|c|c|c|c|}
\hline Variables & 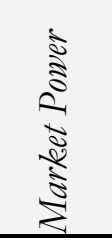 & 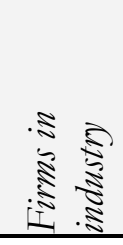 & $\begin{array}{l}7 \\
\sqrt{2} \\
3 \\
5 \\
5\end{array}$ & 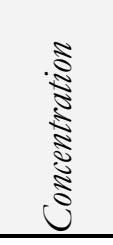 & 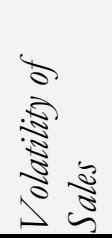 & है & 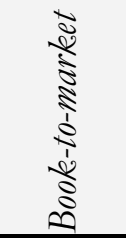 & $\stackrel{\stackrel{\Delta}{\sim}}{\sim}$ & 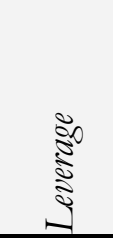 \\
\hline Market Power & 1.000 & -0.170 & 0.445 & 0.010 & 0.028 & 0.030 & -0.050 & 0.094 & 0.159 \\
\hline Num Firms in industry & & 1.000 & -0.276 & -0.290 & -0.008 & 0.068 & 0.041 & 0.043 & -0.075 \\
\hline Industry $L I$ & & & 1.000 & 0.022 & 0.018 & -0.028 & -0.055 & -0.031 & 0.155 \\
\hline Concentration & & & & 1.000 & -0.031 & -0.020 & -0.013 & -0.013 & 0.023 \\
\hline Volatility of Sales & & & & & 1.000 & 0.344 & 0.034 & -0.063 & -0.102 \\
\hline Growth & & & & & & 1.000 & 0.048 & 0.017 & 0.030 \\
\hline Book-to-market & & & & & & & 1.000 & 0.034 & 0.003 \\
\hline Size & & & & & & & & 1.000 & 0.024 \\
\hline Leverage & & & & & & & & & 1.000 \\
\hline
\end{tabular}




\section{Table 3}

\section{Market power and earnings management: Univariate analysis}

This table reports univariate analysis of the relationship between market power quintiles and absolute discretionary accruals. The statistics are based on maximum of 43,628 firm-year spanning 1987-2009 for firms meeting our data requirements. The absolute level of discretionary accruals is computed using modified Jones model with Kothari et al. (2005) adjustment for firm performance. We sort firms each year on the basis of Market Power variable and compute the mean for each market power quintile. Then we take the time-series mean (median) for each market power quintile. The first (last) quintile represents firms with the least (most) market power. Last row provides $\mathrm{p}$-values for difference of mean between first and fifth quintiles.

\begin{tabular}{|c|c|c|c|c|c|c|}
\hline \multirow[t]{2}{*}{$\begin{array}{l}\text { Quintiles Based } \\
\text { on Market Power }\end{array}$} & \multicolumn{2}{|c|}{ Total Sample } & \multicolumn{2}{|c|}{$\begin{array}{c}\text { Positive Absolute } \\
\text { Discretionary } \\
\text { Accruals }\end{array}$} & \multicolumn{2}{|c|}{$\begin{array}{c}\text { Negative Absolute } \\
\text { Discretionary Accruals }\end{array}$} \\
\hline & $\begin{array}{c}\text { Mean } \\
\text { (Median) }\end{array}$ & t-stat & $\begin{array}{c}\text { Mean } \\
\text { (Median) }\end{array}$ & t-stat & $\begin{array}{c}\text { Mean } \\
\text { (Median) }\end{array}$ & t-stat \\
\hline First Quintile & $\begin{array}{c}0.133 \\
(0.119)\end{array}$ & 18.66 & $\begin{array}{c}0.114 \\
(0.098)\end{array}$ & 15.90 & $\begin{array}{c}0.146 \\
(0.133)\end{array}$ & 18.22 \\
\hline Second Quintile & $\begin{array}{c}0.087 \\
(0.079)\end{array}$ & 21.72 & $\begin{array}{c}0.090 \\
(0.078)\end{array}$ & 14.79 & $\begin{array}{c}0.094 \\
(0.080)\end{array}$ & 18.79 \\
\hline Third Quintile & $\begin{array}{c}0.078 \\
(0.075)\end{array}$ & 30.07 & $\begin{array}{c}0.080 \\
(0.073)\end{array}$ & 23.82 & $\begin{array}{c}0.072 \\
(0.063)\end{array}$ & 20.36 \\
\hline Fourth Quintile & $\begin{array}{c}0.072 \\
(0.067)\end{array}$ & 26.60 & $\begin{array}{c}0.075 \\
(0.072)\end{array}$ & 19.16 & $\begin{array}{c}0.072 \\
(0.063)\end{array}$ & 18.40 \\
\hline Fifth Quintile & $\begin{array}{c}0.073 \\
(0.065)\end{array}$ & 25.95 & $\begin{array}{c}0.070 \\
(0.066)\end{array}$ & 18.45 & $\begin{array}{c}0.075 \\
(0.069)\end{array}$ & 23.97 \\
\hline $\begin{array}{l}\mathrm{p} \text {-value for } \\
\text { difference in Q1 } \\
\text { and Q5 means }\end{array}$ & $<0.000$ & & $<0.000$ & & $<0.000$ & \\
\hline
\end{tabular}


Table 4

Market power and earnings management: Absolute discretionary accruals

This table reports the results of OLS regressions examining the impact of market power on discretionary accruals for a sample of firms spanning 1987-2009 that meet our data requirements. The dependent variable is the absolute level of discretionary accrual using modified Jones model with Kothari et al. (2005) adjustment for firm performance. All models include year and industry dummies. All the variables are as defined in earlier tables. P-values reported in the parentheses are computed with standard errors adjusted for firm-level clustering.

\begin{tabular}{|c|c|c|c|c|c|c|}
\hline Independent Variables & Model 1 & Model 3 & Model 4 & Model 5 & Model 6 & Model 7 \\
\hline Market Power & $\begin{array}{c}-0.451 \\
(<0.000)\end{array}$ & $\begin{array}{c}-0.043 \\
(<0.000)\end{array}$ & $\begin{array}{c}-0.045 \\
(<0.000)\end{array}$ & $\begin{array}{c}-0.040 \\
(<0.000)\end{array}$ & $\begin{array}{l}-0.339 \\
(0.000)\end{array}$ & $\begin{array}{c}-0.449 \\
(<0.000)\end{array}$ \\
\hline Institutional Holdings & & $\begin{array}{c}-0.023 \\
(<0.000)\end{array}$ & & & & \\
\hline $\log (1+$ Num of analyst $)$ & & & $\begin{array}{l}-0.109 \\
(0.110)\end{array}$ & & & \\
\hline GIM Index & & & & $\begin{array}{l}-0.023 \\
(0.470)\end{array}$ & & \\
\hline CEO EBC & & & & & $\begin{array}{c}0.555 \\
(0.166)\end{array}$ & \\
\hline Spread & & & & & & $\begin{array}{l}0.0532 \\
(0.015)\end{array}$ \\
\hline Growth & $\begin{array}{c}4.225 \\
(<0.000)\end{array}$ & $\begin{array}{c}4.290 \\
(<0.000)\end{array}$ & $\begin{array}{c}4.219 \\
(<0.000)\end{array}$ & $\begin{array}{c}3.287 \\
(0.001)\end{array}$ & $\begin{array}{c}2.966 \\
(0.000)\end{array}$ & $\begin{array}{c}4.342 \\
(<0.000)\end{array}$ \\
\hline Log (Market-to-Book) & $\begin{array}{c}1.461 \\
(<0.000)\end{array}$ & $\begin{array}{c}1.410 \\
(<0.000)\end{array}$ & $\begin{array}{c}1.452 \\
(<0.000)\end{array}$ & $\begin{array}{c}1.064 \\
(<0.000)\end{array}$ & $\begin{array}{c}1.130 \\
(<0.000)\end{array}$ & $\begin{array}{c}1.553 \\
(<0.000)\end{array}$ \\
\hline Size & $\begin{array}{c}-9.813 \\
(<0.000)\end{array}$ & $\begin{array}{c}-7.648 \\
(<0.000)\end{array}$ & $\begin{array}{c}-9.352 \\
(<0.000)\end{array}$ & $\begin{array}{c}-7.803 \\
(<0.000)\end{array}$ & $\begin{array}{c}-8.818 \\
(<0.000)\end{array}$ & $\begin{array}{c}-9.687 \\
(<0.000)\end{array}$ \\
\hline Leverage & $\begin{array}{c}-2.538 \\
(<0.000)\end{array}$ & $\begin{array}{c}-2.235 \\
(<0.000)\end{array}$ & $\begin{array}{c}-2.513 \\
(<0.000)\end{array}$ & $\begin{array}{l}-1.900 \\
(0.004)\end{array}$ & $\begin{array}{l}-2.732 \\
(0.003)\end{array}$ & $\begin{array}{c}-2.578 \\
(<0.000)\end{array}$ \\
\hline Volatility of Sales & $\begin{array}{c}3.505 \\
(<0.000)\end{array}$ & $\begin{array}{c}3.625 \\
(<0.000)\end{array}$ & $\begin{array}{c}3.519 \\
(<0.000)\end{array}$ & $\begin{array}{c}3.015 \\
(0.000)\end{array}$ & $\begin{array}{c}2.276 \\
(0.005)\end{array}$ & $\begin{array}{c}3.554 \\
(<0.000)\end{array}$ \\
\hline Constant & $\begin{array}{c}0.071 \\
(<0.000)\end{array}$ & $\begin{array}{c}0.089 \\
(<0.000)\end{array}$ & $\begin{array}{c}0.073 \\
(<0.000)\end{array}$ & $\begin{array}{c}0.079 \\
(<0.000)\end{array}$ & $\begin{array}{c}0.048 \\
(<0.000)\end{array}$ & $\begin{array}{c}0.066 \\
(<0.000)\end{array}$ \\
\hline Year Dummy & Yes & Yes & Yes & Yes & Yes & Yes \\
\hline Industry Dummy & Yes & Yes & Yes & Yes & Yes & Yes \\
\hline Number of Obs. & 39,563 & 37388 & 39,563 & 13,013 & 9,282 & 39,408 \\
\hline
\end{tabular}


Table 5

Market power and earnings management: Signed absolute discretionary accruals

This table reports the results of OLS regressions examining the impact of market power on discretionary accruals for a sample of firms meeting our data requirements spanning 1987-2009. In Panels $\mathrm{A}$ and $\mathrm{B}$, the dependent variables are respectively the positive and negative absolute discretionary accrual using modified Jones model with Kothari et al. (2005) adjustment for firm performance. All models include year and industry dummies. Firm characteristic control variables are suppressed for brevity. All the variables are as defined in Appendix. P-values reported in the parentheses are computed with standard errors adjusted for firm-level clustering.

\begin{tabular}{|c|c|c|c|c|c|c|}
\hline \multicolumn{7}{|c|}{ Panel A: Positive Absolute Discretionary Accruals } \\
\hline Independent Variables & Model 1 & Model 3 & Model 3 & Model 4 & Model 5 & Model 6 \\
\hline Market Power & $\begin{array}{c}-0.024 \\
(<0.000)\end{array}$ & $\begin{array}{c}-0.023 \\
(<0.000)\end{array}$ & $\begin{array}{c}-0.025 \\
(<0.000)\end{array}$ & $\begin{array}{l}-0.026 \\
(0.002)\end{array}$ & $\begin{array}{l}-0.014 \\
(0.050)\end{array}$ & $\begin{array}{c}-0.024 \\
(<0.000)\end{array}$ \\
\hline Institutional Holdings & & $\begin{array}{c}-0.001 \\
(<0.000)\end{array}$ & & & & \\
\hline $\log (1+$ Num. of analyst $)$ & & & $\begin{array}{c}-0.007 \\
(<0.000)\end{array}$ & & & \\
\hline GIM Index & & & & $\begin{array}{c}0.001 \\
(0.079)\end{array}$ & & \\
\hline CEO EBC & & & & & $\begin{array}{l}0.0005 \\
(0.460)\end{array}$ & \\
\hline Spread & & & & & & $\begin{array}{c}0.082 \\
(0.005)\end{array}$ \\
\hline Firm characteristic controls & Yes & Yes & Yes & Yes & Yes & Yes \\
\hline Year \& Industry dummies & Yes & Yes & Yes & Yes & Yes & Yes \\
\hline Number of Obs. & 19,154 & 18,058 & 19,154 & 5,820 & 4209 & 17,648 \\
\hline \multicolumn{7}{|c|}{ Panel B: Negative Absolute Discretionary Accruals } \\
\hline Market Power & $\begin{array}{c}-0.067 \\
(<0.000)\end{array}$ & $\begin{array}{c}-0.064 \\
(<0.000)\end{array}$ & $\begin{array}{c}-0.067 \\
(<0.000)\end{array}$ & $\begin{array}{l}-0.057 \\
(0.002)\end{array}$ & $\begin{array}{l}-0.055 \\
(0.000)\end{array}$ & $\begin{array}{c}-0.066 \\
(<0.000)\end{array}$ \\
\hline Institutional Holdings & & $\begin{array}{l}-0.001 \\
(0.000)\end{array}$ & & & & \\
\hline $\log (1+$ Num. of analyst $)$ & & & $\begin{array}{c}0.004 \\
(0.000)\end{array}$ & & & \\
\hline GIM Index & & & & $\begin{array}{l}-0.001 \\
(0.059)\end{array}$ & & \\
\hline CEO EBC & & & & & $\begin{array}{c}0.007 \\
(0.179)\end{array}$ & \\
\hline Spread & & & & & & $\begin{array}{c}0.033 \\
(0.253)\end{array}$ \\
\hline Firm characteristic controls & Yes & Yes & Yes & Yes & Yes & Yes \\
\hline Year \& Industry dummies & Yes & Yes & Yes & Yes & Yes & Yes \\
\hline Number of Obs. & 20,409 & 19,330 & 20,409 & 7,193 & 5,073 & 21,760 \\
\hline
\end{tabular}




\section{Table 6}

\section{Industry competition and earnings management}

This table reports the results of OLS regressions examining the impact of market power on discretionary accruals for a sample of firms meeting our data requirements spanning 1987-2009. The dependent variable is the absolute level of discretionary accrual using modified Jones model with Kothari et al. (2005) adjustment for firm performance. All the variables are as defined in earlier tables. All variables are averaged for each Fama and French industry grouping with the average values used in the regressions. Firm characteristic control variables are suppressed for brevity in Panel B. P-values reported in the parentheses are computed with standard errors adjusted for industry-level clustering.

\begin{tabular}{cccc}
\hline \multicolumn{4}{c}{ Panel A: Total Sample } \\
\hline & Industry LI & Concentration & Inverse of \# of Firms \\
\hline Independent Variables & Model 1 & Model 2 & Model 3 \\
\hline Industry Measure & -0.031 & -2.836 & -45.355 \\
Growth & $(0.004)$ & $(0.075)$ & $(0.029)$ \\
& 7.738 & 7.605 & 7.511 \\
Log (Market-to-Book) & $(0.001)$ & $(0.001)$ & $(0.001)$ \\
& 2.536 & 3.031 & 2.625 \\
Volatility of Sales & $(0.000)$ & $(<0.000)$ & $(0.000)$ \\
& 0.014 & 0.002 & 0.006 \\
Size & $(0.501)$ & $(0.912)$ & $(0.781)$ \\
& -10.265 & -12.082 & -11.357 \\
Leverage & $(0.001)$ & $(0.000)$ & $(0.001)$ \\
& -12.217 & -13.649 & -14.002 \\
Constant & $(0.021)$ & $(0.007)$ & $(0.005)$ \\
\multirow{2}{*}{ Year Dummy } & 0.752 & 0.0745 & 0.081 \\
Number of Obs. & $(0.000)$ & $(<0.000)$ & $(<0.000)$ \\
& Yes & Yes & Yes \\
\hline
\end{tabular}

Panel B: Positive and Negative Absolute Discretionary Accruals Separately

\begin{tabular}{cccccccc}
\hline \multirow{2}{*}{ Independent Variables } & Pos DA & Neg DA & Pos DA & Neg DA & Pos DA & Neg DA \\
\cline { 2 - 7 } & \multicolumn{2}{c}{ Industry LI } & \multicolumn{2}{c}{ Concentration } & \multicolumn{2}{c}{ Inverse of \# of Firms } \\
\cline { 2 - 7 } & Mode1 1 & Mode1 2 & Model 3 & Model 4 & Model 5 & Model 6 \\
\hline Industry Measure & -0.040 & -0.030 & -2.448 & -3.359 & -55.074 & -38.378 \\
Firm Characteristic & $(0.001)$ & $(0.008)$ & $(0.072)$ & $(0.085)$ & $(0.047)$ & $(0.115)$ \\
Controls & Yes & Yes & Yes & Yes & Yes & Yes \\
Year Dummy & Yes & Yes & Yes & Yes & Yes & Yes \\
\hline Number of Obs. & 953 & 953 & 953 & 953 & 953 & 953 \\
\hline
\end{tabular}

